Sains Malaysiana 47(1)(2018): 169-179

http://dx.doi.org/10.17576/jsm-2018-4701-20

\title{
Effect of the Poly L-lactic Acid Coating on the Corrosion of Magnesium in Hank's Solution
}

(Kesan Salutan Acid L-laktik Poli ke atas Pengkakisan Magnesum dalam Larutan Hanks)

\author{
ATIKAH WAN NAFI*, AMALINA AFIFI, NOR ISHIDA ZAINAL ABIDIN, \\ NOOR HIDAYAH ABDUL AZIZ \& KATAYOON KALANTARI
}

\begin{abstract}
To control the corrosion rate, the Magnesium (Mg) was coated with poly (l-lactic acid) (PLLA) using electrospinning technique. The effectiveness of the PLLA coating on the high purity Magnesium (HP Mg) and alloy AZ91 were tested in Hank's solution immersion test. The corrosion behaviour of Mg coated PLLA was studied through hydrogen evolution, weight loss and scanning electron microscope (SEM) before, during and after samples were immersed. The solution was maintained at $\mathrm{pH} 7$ by bubbling $\mathrm{CO}_{2}$ gas. The results showed that surface treatment on $\mathrm{Mg}$ by coating with PLLA had reduced the rate of corrosion during the immersion test. The PLLA coating was also characterized and the coating adhesion was evaluated.
\end{abstract}

Keywords: Magnesium; SEM and PLLA coating; weight loss

ABSTRAK

Bagi mengawal kadar kakisan Magnesium; Mg disalut dengan asid (l-laktik) poli; PLLA menggunakan teknik putaran elektron. Keberkesanan PLLA yang membaluti HP Mg dan aloi AZ91 diuji dengan merendam di dalam cecair Hanks. Ciri-ciri kakisan oleh Mg bersalut PLLA dikenal pasti melalui pelepasan hidrogen, penurunan berat dan pengimbas mikroskop elektron (SEM) sebelum, semasa dan selepas sampel direndamkan. Cecair tersebut sentiasa berada pada pH 7 dengan aliran gas $\mathrm{CO}_{2}$ Keputusan menunjukkan bahawa kaedah rawatan kepada permukaan magnesium dengan disaluti PLLA telah menurunkan kadar kakisan semasa ujian rendaman. Salutan PLLA juga dikenal pasti dan kelekatan balutan juga diuji.

Kata kunci: Magnesium; penurunan berat; SEM dan salutan PLLA

\section{INTRODUCTION}

Medical implants are made from many types of alloys, such as $316 \mathrm{~L}$ stainless steel, titanium alloys and cobalt based alloys. These are permanent implants need to be removed after bones are healed. Implant removal is important after bone healing because long term implantation can cause risks such as local inflammation as metal implant is a foreign material to the human body. The removal surgery increase the patient morbidity and the cost of health care due to longer hospitalization (Chu et al. 2002; Song 2007; Wen et al. 2009; Wong et al. 2010). To solve this problem, magnesium $(\mathrm{Mg})$ has gain lot of interest to be used for biodegradable implants. $\mathrm{Mg}$ has density of 1.74 $\mathrm{g} / \mathrm{cm}^{3}$ which is less than steel and aluminium. The elastic modulus and compressive yield strength of $\mathrm{Mg}$ are closer to natural bone compared with other metal (Abdalla et al. 2014; Cao et al. 2013; Chiu et al. 2007; Staiger et al. 2006). Furthermore, $\mathrm{Mg}$ is degradable, environmentally friendly, essential to human metabolism and inexpensive. Moreover, there is growing evidence that slow release of $\mathrm{Mg}$ ions to human body is harmless. Unfortunately, Mg alloys have disadvantage that limit their use particularly in biomedical application. A major concern is its low corrosion resistance which may cause total corrosion of the $\mathrm{Mg}$ implant before the wound is healed. The environment, surface properties, alloy chemistry and metal impurities are factors that affect the corrosion behaviour of $\mathrm{Mg}$. Therefore, biodegradable polymer coatings might be applied to increase the corrosion resistance, antimicrobial action, dielectric strength and wear properties (Abdalla et al. 2014, 2012; Iafisco et al. 2011; Ravichandran 2009). Electrospun fibre meshes have received significant attention as growth substrates for cells and tissues, mainly due to their morphology and the dimension of the nanofibres that mimicks natural cells (Chen et al. 2012; Doshi \& Reneker 1995; Duan et al. 2007; Frenot \& Chronakis 2003; Shah et al. 2009). This work studied the influence of electrospun PLLA nanofiber coating on the corrosion of high-purity $\mathrm{Mg}$ ( $\mathrm{HP} \mathrm{Mg}$ ) and alloy AZ91. AZ91 contains 9\% $\mathrm{Al}$ and $1 \% \mathrm{Zn}$.

\section{MATERIALS AND METHODS}

\section{PREPARATION OF MAGNESIUM SPECIMENS}

Specimens with dimensions of length $\times$ width $\times$ thickness $(10 \mathrm{~mm} \times 10 \mathrm{~mm} \times 5 \mathrm{~mm})$ were cut from $\mathrm{HP} \mathrm{Mg}$ and 
AZ91 ingots, respectively. All specimen surfaces were mechanically polished with 600-1200 grit silicon carbide $(\mathrm{SiC})$ papers and cleaned with ethanol and distilled water. Six samples of HP Mg and AZ91 were prepared and a hole with diameter of $1.0 \mathrm{~mm}$ was drilled through each sample. Another six samples of HP Mg and AZ91 were prepared without hole. These samples were then divided to: a) non-coated HP Mg and AZ91 and b) coated PLLA-HP $\mathrm{Mg}$ and PLLA-AZ91. Samples with hole were designated as 1,2 and 3 while samples without hole were designated as 4, 5 and 6. Samples with introduced hole can be used in further implantation into animal which it is preventing mobilization in tissue study.

\section{PREPARATION OF PLLA COATED Mg SPECIMENS BY ELECTROSPINNING}

The electrospinning apparatus consisted of three components: spinneret, collector and voltage power. PLLA $\left(\mathrm{Mw}=1.63 \times 10^{5} \mathrm{~g} \cdot \mathrm{mol}^{-1}\right)$ solution was prepared by dissolving 8 wt. \% PLLA (Mitsui Chem. Co. Ltd.) in chloroform at room temperature. The solution was fed into a $10 \mathrm{~mL}$ syringe with thin needle (27 G; inner diameter (ID) $0.21 \mathrm{~mm}$ and outer diameter (OD) $0.42 \mathrm{~mm}$ ) and installed on a syringe pump. PLLA dope was extruded from the syringe at a constant rate of $1.00 \mathrm{ml} / \mathrm{h}, 10 \mathrm{kV}$ of applied voltage and a tip-to-collector distance of $15 \mathrm{~cm}$ (Amalina et al. 2009). The coating of each surface was done for $1 \mathrm{~h}$ to obtain well covered surface. The coated samples then kept in the desiccator before immersion test.

\section{COATING CHARACTERIZATION}

The PLLA coating layer on the Mg surfaces were characterised using X-ray diffractometer (XRD PANalytical $\mathrm{X}$ 'Pert High Score) with copper $\mathrm{K} \alpha$ radiation at a glancing angle of $1^{\circ}$ at $45 \mathrm{kV}$ and $40 \mathrm{~mA}$. The purity of PLLA coating was determined using Fourier transform infrared spectroscopy (FTIR Perkin Elmer). Spectra were obtained over the frequency range of $4000-400 \mathrm{~cm}^{-1}$. The surface morphology was observed using scanning electron microscopy (SEM) equipped with energy dispersive spectroscopy. The microscratch test (CORE Nano-scratch,
Micro Materials) was conducted to measure the thickness and the strength of the coating on the surface.

\section{IMMERSION TEST}

All tests were done by hanging the samples with fishing line as shown in Figure 1.

Each sample was immersed for 14 days at $37 \pm 2{ }^{\circ} \mathrm{C}$ in 0.5 L Hanks' solution. Hanks' solution was made by mixing Hanks' balanced salt (without sodium bicarbonate and phenol red, Sigma Aldrich), sodium bicarbonate (reagent grade) and distilled water (Abidin et al. 2013; Qiao et al. 2012). The solution was maintained at $\mathrm{pH} 7$ constantly by bubbling $\mathrm{CO}_{2}$ at a partial pressure of 0.009 atm throughout the immersion test (Zainal Abidin et al. 2011). The corrosion rate was evaluated by: the hydrogen evolution volume and the weight loss over the whole duration of immersion. The overall $\mathrm{Mg}$ corrosion reaction is given by:

$$
\mathrm{Mg}+2 \mathrm{H}_{2} \mathrm{O} \rightarrow \mathrm{Mg}^{2}+2 \mathrm{OH}^{-}+\mathrm{H}_{2}
$$

Equation (1) indicates that each atom of corroded $\mathrm{Mg}$ causes the evolution of one molecule of hydrogen. The weight of $\mathrm{Mg}$ was taken in three steps: before immersion test, after immersion test before removal of corrosion product and after removal of corrosion product. The samples were dried in a desiccator for 1-2 days before weighing. Hydrogen evolved was collected directly by a filter funnel into burette above corroding specimen. After each immersion test, the specimen was removed from the solution and dried in the desiccators for 1-2 days.

\section{CORROSION EVALUATION}

Hydrogen evolution is a common method by which to evaluate Mg corrosion (Atrens et al. 2011; Virtanen 2011). The measured volume of evolved hydrogen was converted to the equivalent volume at the standard temperature $\left(0^{\circ} \mathrm{C}\right)$ and pressure (1 atm) using the ideal gas law. The corrosion rate $P_{\mathrm{AH}}\left(\mathrm{mm} \mathrm{y}^{-1}\right)$ was evaluated using:

$$
P_{\mathrm{AH}}=2.279 V_{\mathrm{H}}
$$

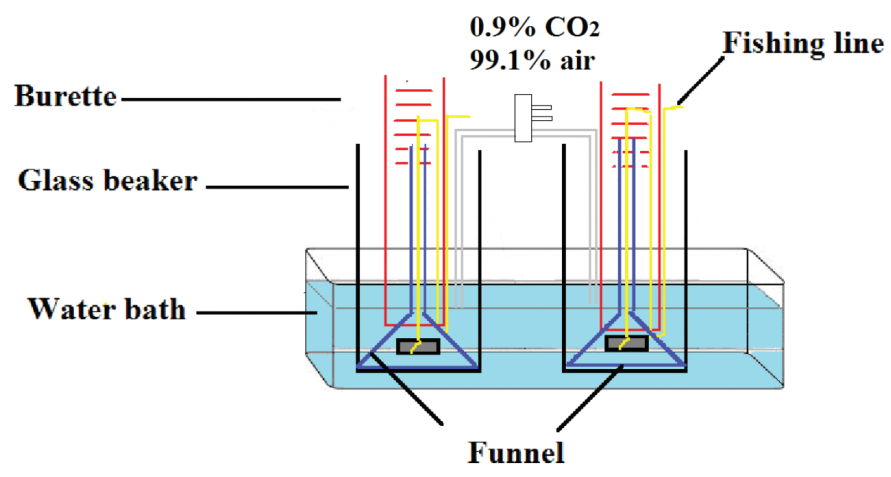

FIGURE 1. Schematic showing an immersion test of specimen hung with fishing line 
where $V_{\mathrm{H}}\left(\mathrm{mL} \mathrm{cm}^{-2} \mathrm{~d}^{-1}\right)$ is the volume of evolved hydrogen per unit area per day.

The corrosion products were removed by immersion of each specimen in chromic acid cleaning solution at room temperature for $10 \mathrm{~min}$. This chromic acid cleaning solution contained $200 \mathrm{~g} \mathrm{~L}^{-1} \mathrm{CrO}_{2}$ and $10 \mathrm{~g} \mathrm{~L}^{-1} \mathrm{AgNO}_{2}$.

After cleaning, each of the specimens was washed with distilled water and dried in a desiccator for 1-2 days. The weight loss rate, $W_{\mathrm{L}}\left(\mathrm{mg} \mathrm{cm} \mathrm{cm}^{-2} \mathrm{day}^{-1}\right)$ was calculated using:

$$
W_{L}=\left(W_{b}-W_{a}\right) / A t
$$

where $W_{\mathrm{b}}(\mathrm{mg})$ was the weight of $\mathrm{Mg}$ before the immersion test, $W_{\mathrm{a}}(\mathrm{mg})$ was the weight after the immersion test and after removal of corrosion product, $A$ is the specimen surface area $\left(\mathrm{cm}^{2}\right)$ and $t$ is the immersion duration in days (d). The weight loss was converted to the (average) corrosion rate, $P_{\mathrm{w}}\left(\mathrm{mm} \mathrm{y}^{-1}\right)$ using (Shi \& Atrens 2011; Zhao et al. 2009, 2008):

$$
P_{W}=2.1 \Delta W
$$

The surface of the $\mathrm{Mg}$ samples was characterized by scanning electron microscopy (SEM) coupled with an energy dispersive X-ray spectroscopy before and after corrosion product removal.

\section{RESULTS AND DISCUSSION}

\section{CHEMICAL COMPOSITION OF MAGNESIUM SPECIMENS}

The chemical compositions of HP Mg and AZ91 are listed in Table 1. HP Mg is a standard that has been used to compare the AZ91. AZ91 is the mostly used casting alloy and it is usually consisting of $9 \% \mathrm{Al}$ and $1 \% \mathrm{Zn}$.

\section{COATING CHARACTERIZATION}

In order to confirm the formation of electrospun PLLA layer on the HP Mg and AZ91, XRD analysis was used and shown in Figure 2 and 3.

The XRD results demonstrate that $\mathrm{Mg}$ peaks can be clearly identified from both Figure 2 and Figure 3 at $32^{\circ}, 35^{\circ}, 37^{\circ}, 50^{\circ}, 57^{\circ}, 63^{\circ}, 69^{\circ}, 70^{\circ}$ and $78^{\circ}$ at $2 \Theta$ angles. The XRD diffraction peaks at $2^{\circ}$ angle of $16^{\circ}$ attributed to amorphous PLLA. This observation is due to the thickness of PLLA layer coated on Mg and AZ91 (Abdalla et al.2014; Niu et al. 2013; Razavi et al.2014). This finding is similar with previous research where the diffractions of PLLA were not sharp and the peak usually at $2 \Theta$ angle of $16^{\circ}$ (Amalina et al. 2009; Krikorian \& Pochan 2003). To verify the existence of chemical structure changes of the polymeric matrix on $\mathrm{Mg}$ sample, FTIR spectra were obtained. In Figure 4 , broad transmittance bands were observed at $3250 \mathrm{~cm}^{-1}$ to $3500 \mathrm{~cm}^{-1}$. Transmittance bands were also detected at $2256-2500 \mathrm{~cm}^{-1}, 1750 \mathrm{~cm}^{-1}$ and $945 \mathrm{~cm}^{-1}$. Figure 5 presents the schematic illustration of determination of the PLLA
TABLE 1. Chemical composition of (HP Mg) and AZ91

\begin{tabular}{ccc}
\hline Element & $($ HP Mg,wt. \%) & (AZ91, wt. \%) \\
\hline $\mathrm{Mg}$ & Balance & Balance \\
$\mathrm{Al}$ & 0.0088 & 8.15 \\
$\mathrm{Zn}$ & 0.02 & 0.64 \\
$\mathrm{Mn}$ & 0.02 & 0.15 \\
$\mathrm{Cu}$ & 0.002 & 0.001 \\
$\mathrm{Fe}$ & 0.007 & 0.0046 \\
$\mathrm{Ni}$ & 0.0001 & 0.0031 \\
$\mathrm{Ca}$ & $<0.005$ & $<0.01$ \\
$\mathrm{Be}$ & $<0.0001$ & $<0.0001$ \\
$\mathrm{Ce}$ & $<0.01$ & $<0.01$ \\
$\mathrm{Gd}$ & $<0.01$ & $<0.01$ \\
$\mathrm{La}$ & $<0.01$ & $<0.01$ \\
$\mathrm{Nd}$ & $<0.01$ & $<0.01$ \\
$\mathrm{Pr}$ & $<0.01$ & $<0.01$ \\
$\mathrm{Y}$ & $<0.01$ & $<0.01$ \\
\hline
\end{tabular}

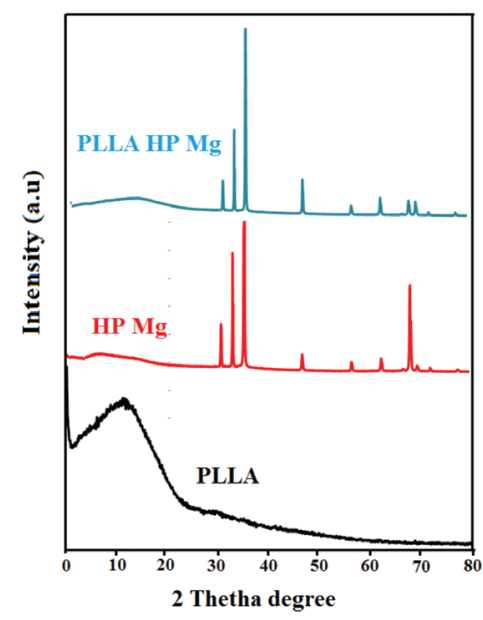

FIGURE 2. XRD spectra of PLLA-HP $\mathrm{Mg}$ and $\mathrm{HP} \mathrm{Mg}$

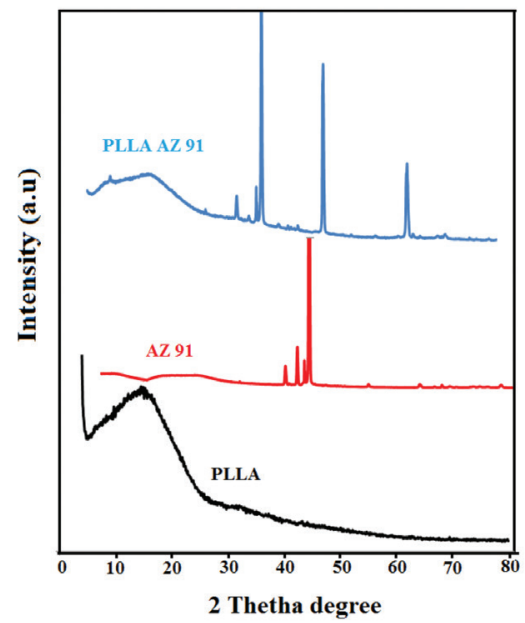

FIGURE 3. XRD spectra of PLLA-AZ91 and uncoated AZ91 
layer thickness and adhesion strength of layer on the $\mathrm{Mg}$ surface from the microscratch test.

The thickness was based on the penetration depth of the indenter tip until it reached the $\mathrm{Mg}$ surface. The adhesion strength was based on load applied in which first failure occurred. The thickness of PLLA layer on $\mathrm{Mg}$ surface was found to be $17.83 \mu \mathrm{m}$ and the adhesion strength obtained was $415.47 \mathrm{mN}$.

Figure 6 presents the surface morphologies of coated PLLA samples. Both PLLA-HP Mg and only one PLLA-AZ91 samples have an irregular, numerous junctions, undulating morphology with large variations in diameter along a single fibre. The fibres mats were smooth and beadles showing the bonding of intersecting fibres had created a strong cohesive and well adherence with metal substrate (Agrawal \& Ray 2001; Deitzel et al. 2001).

The diameters of fibres were ranging from $369 \mathrm{~nm}$ to $1.29 \mu \mathrm{m}$. Even though the substrate used for PLLA-
AZ91 2 was similar with PLLA-AZ91 5, beadings were formed on surface. There are other parameters affecting electrospinning process such as solution properties, set up variables and ambient condition. Due to chemical stability of polymer can degraded over time, the chemical properties of polymer solution also changed. Polymer degradation will lead to impurities of solution that jet from the needle to collector and formed fiber with bead. (Abdalla et al. 2013; Frenot \& Chronakis 2003; Liang et al. 2007; Shenoy et al. 2005). From observation of SEM images, non-uniform fibres were more easily to form with high molecular weight PLLA (Azad et al. 2008; Iafisco et al.2011). The EDX results show that all samples before immersion test were mainly composed of $\mathrm{C}, \mathrm{O}$ and $\mathrm{Mg}$.

\section{CORROSION EVALUATION}

The corrosion evaluation of immersed samples was determined by $\mathrm{H}_{2}$ gas evolution, weight loss and SEM-EDX.

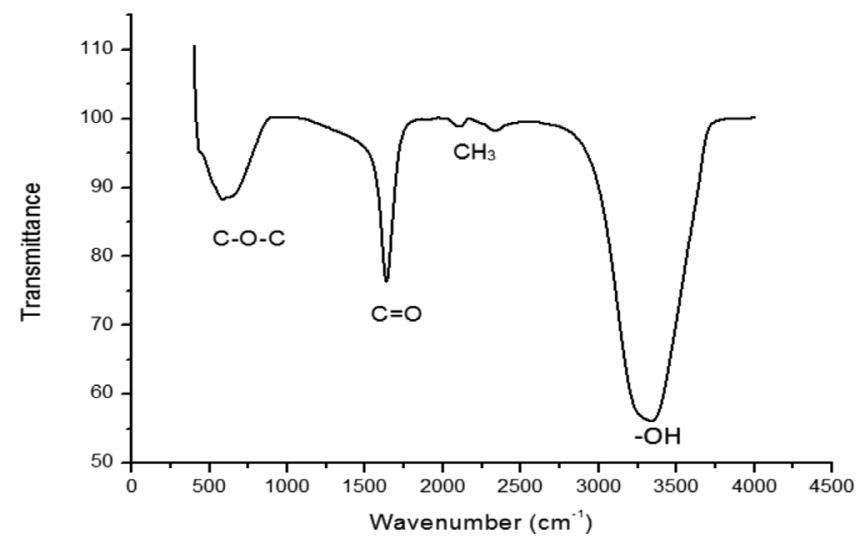

FIGURE 4. FT-IR spectra of PLLA-HP Mg

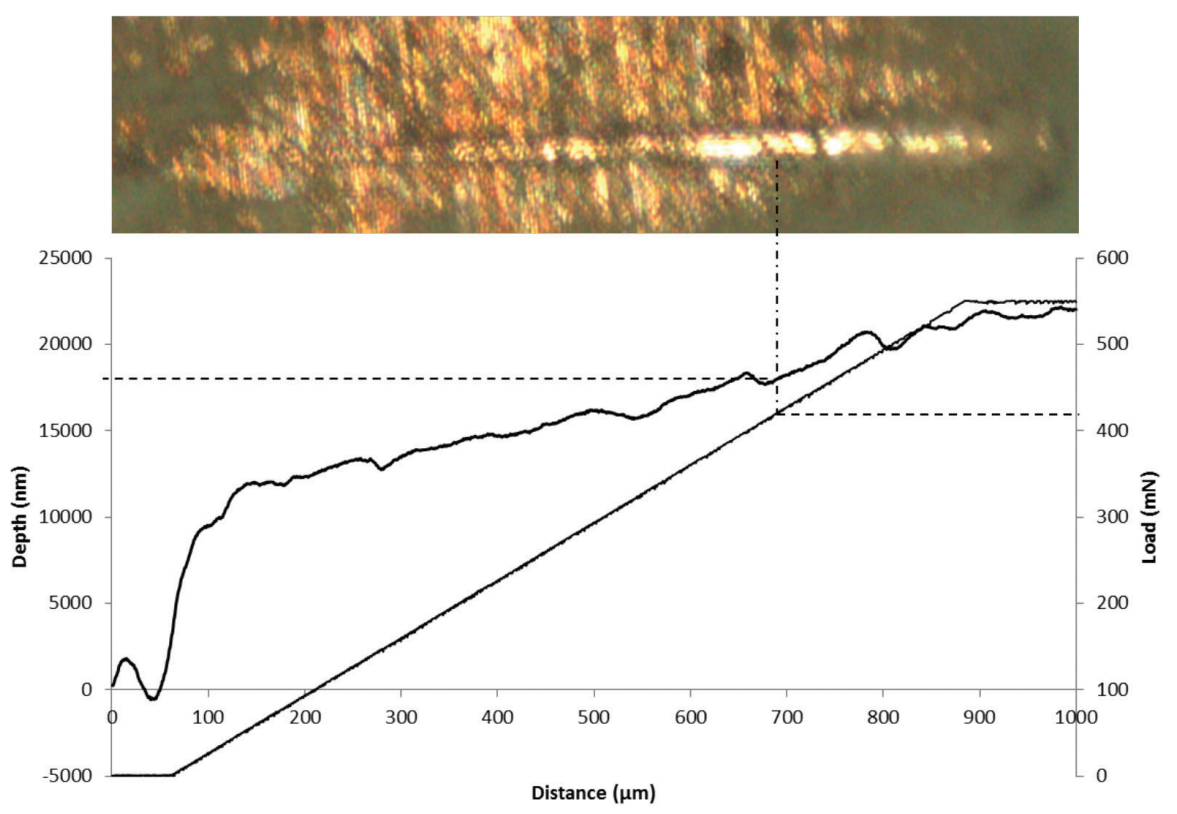

FIGURE 5. Schematic illustration of determination of the PLLA layer thickness and adhesion strength on $\mathrm{Mg}$ surface 

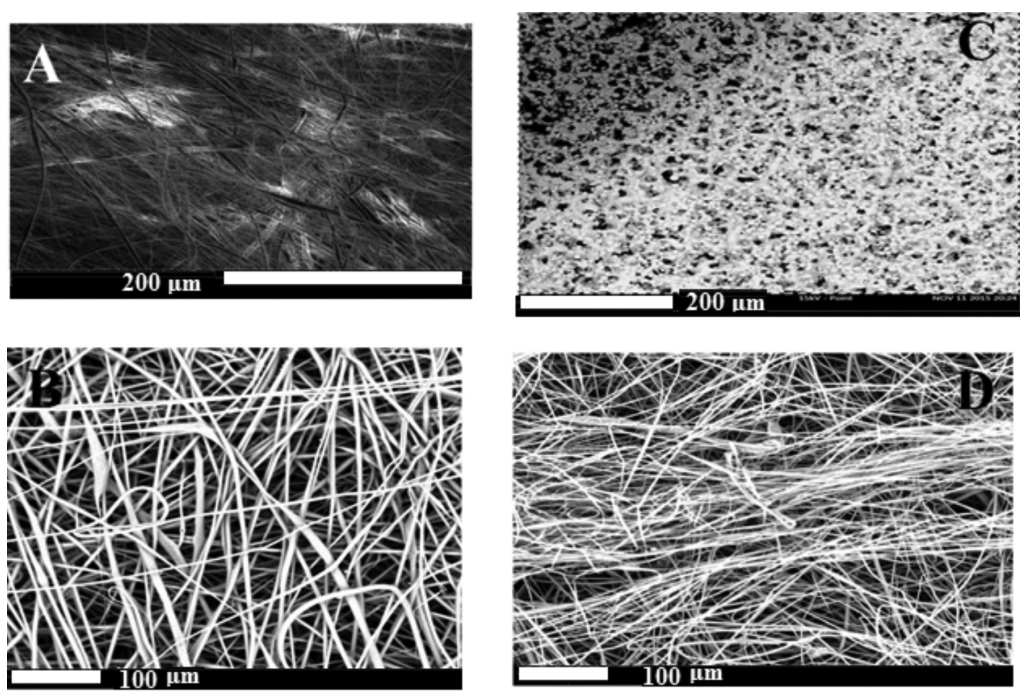

FIGURE 6. SEM surface morphologies of PLLA-HP Mg 1 (A), PLLA-HP Mg 5 (B), PLLA-AZ91 2 (C) and PLLA-AZ91 5 (D)

The $\mathrm{pH}$ value was monitored throughout the immersion test. The $\mathrm{pH}$ was approximately kept constant within 7.07.8 for all samples by bubbling $\mathrm{CO}_{2}$ with partial pressure of 0.009 atm into Hanks' solution at $37 \pm 2{ }^{\circ} \mathrm{C}$. Figure 7 presents the corrosion behaviour of samples with hole from the hydrogen evolution obtained throughout the immersion test.

Hydrogen volume evolved for samples without hole are shown in Figure 8.

The open symbol indicated the hydrogen evolution volume and full symbols corresponds to the $\mathrm{pH}$ of the solution during immersion test. HP Mg 2 and PLLA-AZ91 1 samples have been omitted due to technical error. Thus, it was not possible to report hydrogen evolution data and the corrosion rate, $\mathrm{P}_{\mathrm{AH}}$ for these specimens. All samples show that the hydrogen evolution volume had increased with the immersion time. The result showed similar trend with previous study (Atrens et al. 2011). All samples with hole did not have incubation period except AZ91 3 and PLLA-AZ91 2. The incubation periods for both samples were up to $125 \mathrm{hr}$ and $100 \mathrm{hr}$ respectively. During the incubation period, the rate was low and then increased with increasing immersion time and typically reached a steady state value. The corrosion rate of AZ91 3 had rapidly increases after incubation period whereas PLLAAZ91 2 increased moderately. AZ91 3 had the highest total hydrogen evolution volume in comparison with other uncoated AZ91 samples even though it was initially incubated. It was observed that for samples with hole, the hydrogen volume of coated PLLA-HP Mg were slightly
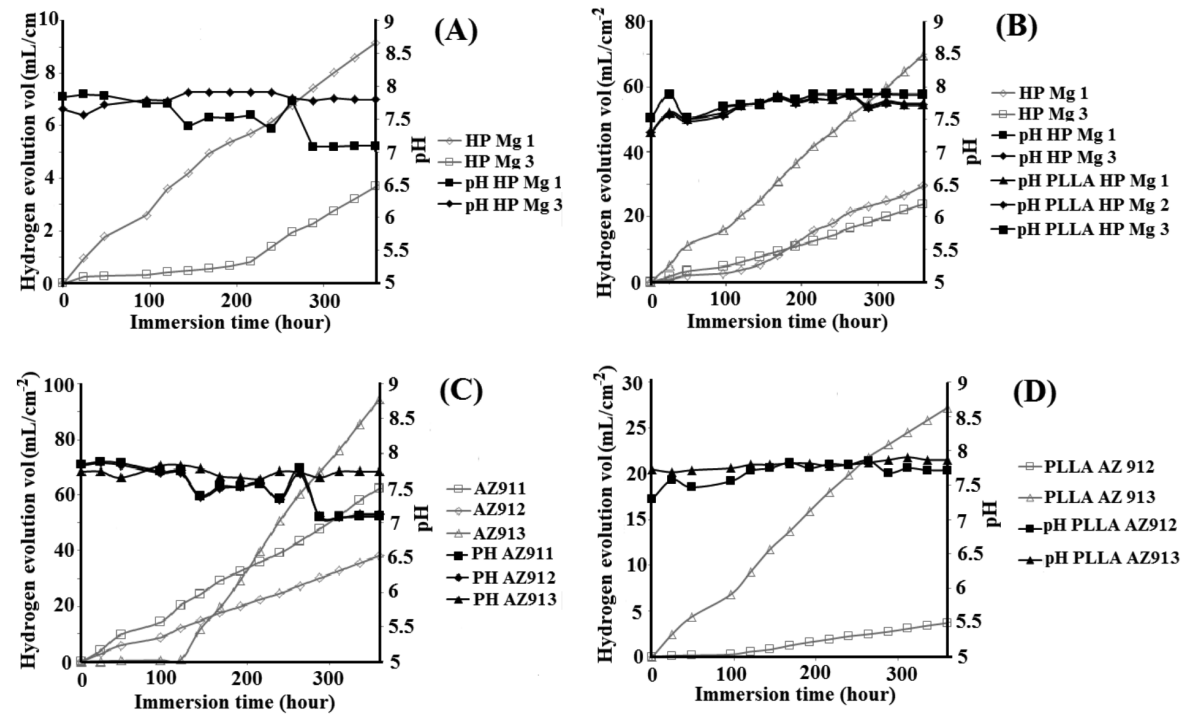

FIGURE 7. Hydrogen evolution of HP Mg (A), PLLA-HP Mg (B), AZ91 (C) and PLLA-AZ91(D), (with hole) in Hank's solution 

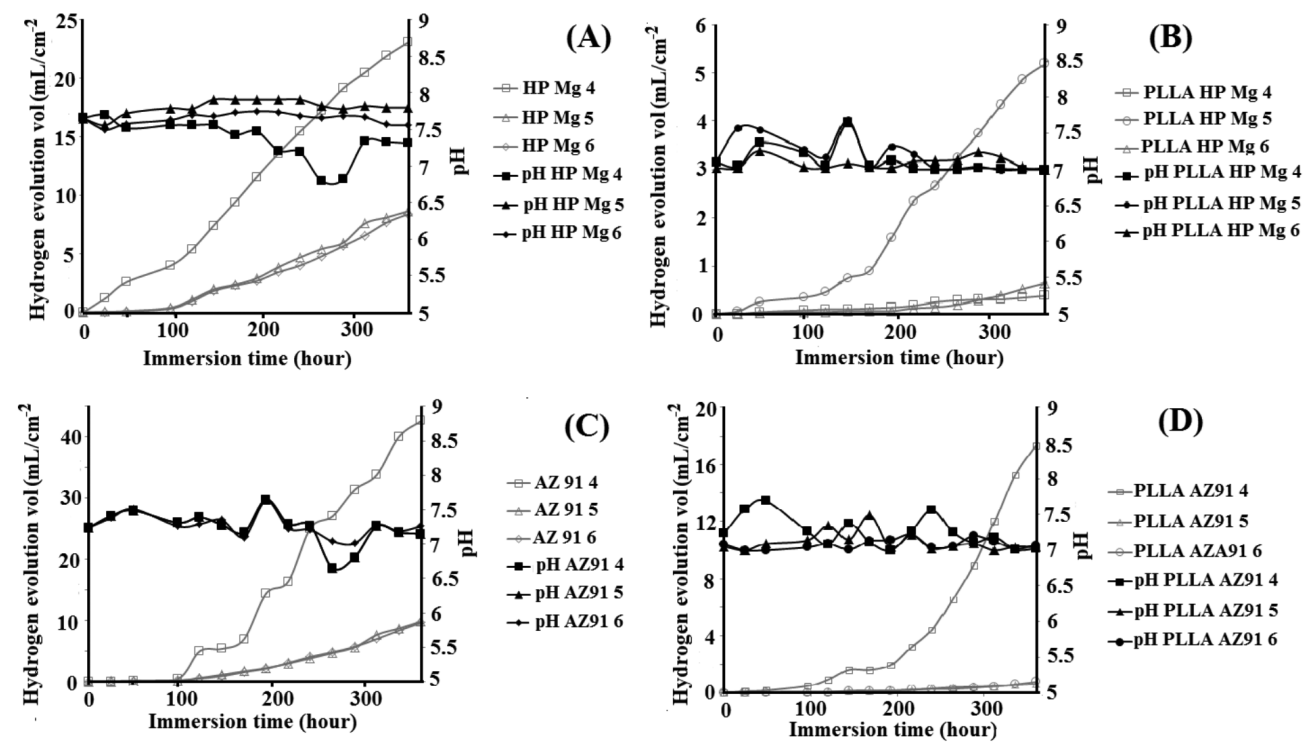

FIGURE 8. Hydrogen evolution of HP Mg (A), PLLA-HP Mg (B), AZ91 (C) and AZ91 (D), (without hole) in Hank's solution

higher than uncoated HP Mg. It has been stated by previous finding that $\mathrm{Mg}$ surface is unstable and surface modification can improve its stability. However, modification used can be toxic and may not sufficiently improve the degradation behaviour of $\mathrm{Mg}$. This also may attribute to the polymer on the surface gradually became more hydrophilic in aqueous environments (Abdalla et al. 2012; Krikorian \& Pochan 2003; Pandey et al. 2008; Zhang \& Ma 1998). However, the hydrogen volumes of non- coated AZ91 with hole were higher than coated samples AZ91 with hole. All samples without hole had incubation period except HP Mg 4. The incubation period was longest for the two samples PLLAHP Mg 4 and PLLA-HP Mg 6 up to $200 \mathrm{hr}$ and was shortest for PLLA-HPMg 5. PLLA-HP Mg 5 fluctuates increased after incubated up to $25 \mathrm{~h}$. The incubation period of both noncoated HP Mg was up to $100 \mathrm{hr}$ except for HP Mg 4. HP $\mathrm{Mg} 4$ had the highest total hydrogen evolution volume in comparison with two other uncoated HP Mg. All non-coated AZ91 samples without hole were incubated up to $100 \mathrm{~h}$. AZ91 4 had the higher corrosion rate in comparison with other uncoated AZ91 even though it had similar incubation period. The hydrogen evolution volume of PLLA-AZ91 5 and PLLA-AZ91 6 increased slowly throughout 14 days of immersion test after having incubation period up to $125 \mathrm{~h}$. The hydrogen evolution volume of PLLA-AZ91 4 slightly increased after incubated until $50 \mathrm{~h}$ before increased rapidly. Two out of triplicate samples from each Mg samples without hole showed similar behaviour. In general, samples without hole and well coated with PLLA have lower volume of hydrogen evolution. It proved that surface modification onto Mg surface with PLLA possibly reduced the volumes of hydrogen evolved and also reduced the corrosion rates of $\mathrm{Mg}$. This result is also suggested by previous studies in which by coating the anodic (metal) can reduce the corrosion rate (Song 2007). For each specimen that have incubation period, it showed low hydrogen gas evolved and typically tending to steady state value. After incubation period, some samples such as PLLA-HP Mg 5, PLLA-AZ91 4 and AZ91 4 showed rapidly increased in hydrogen evolution volume. This behaviour consistent with prior observation of similar corrosion behaviour for $\mathrm{Mg}$ alloys. It is expected that the initiation and propagation of the heterogeneous corrosion is a stochastic process and the variability may be because AZ91 was die casting and some rare impurities particles, thus the resultant corrosion rate is significantly greater than normal specimen. In general, corrosion rate of $\mathrm{Mg}$ alloy tend to be greater than high purity $\mathrm{Mg}$ due to alloying metal (impurities) but with surface coating, corrosion resistance of alloy can be improved particularly during initial stages as it successfully delayed biodegradation of substrate (Rojaee et al.2013). As shown in Figures 7 and 8, the pH of uncoated HP Mg and AZ91 started at around 7.8 and decreased with increased immersion time while both coated $\mathrm{HP} \mathrm{Mg}$ and AZ91 remained in between 7.0 and 7.88. This means corrosion reaction for uncoated $\mathrm{Mg}$ and alloy tend to be active in the beginning of immersion time compared to coated specimen as it is protected by layer of polymer coating. Hence, the corrosion reaction tends to slow down at the beginning of immersion time. Certain conditions of the environment play an important role for the corrosion properties of metals in surface reaction. Metal corrosion and biological reaction can influence the $\mathrm{pH}$ changes. Surface alkalization due to $\mathrm{Mg}$ dissolution can lead to high alkalinity (Razavi et al. 2014). It means $\mathrm{pH}$ will increase upon $\mathrm{Mg}$ corrosion in which hydrogen gas and oxygen gas reduction play role. Table 2 shows the weight loss data, $\mathrm{W}_{\mathrm{L}}$ the corresponding corrosion rate, $\mathrm{P}_{\mathrm{w}}$, the hydrogen evolution rate, $\mathrm{V}_{\mathrm{TH}}$, and the corresponding corrosion rate, $\mathrm{P}_{\mathrm{AH}}$ for all specimens in Hank's solution for 14 days. 
TABLE 2. Corrosion rate of HP Mg, AZ91, PLLA-HP Mg and PLLA-AZ91 in Hank's solution

\begin{tabular}{|c|c|c|c|c|}
\hline Material & Sample & $\begin{array}{l}\text { Immersion period } \\
\text { (hour) }\end{array}$ & $\begin{array}{c}\mathrm{P}_{\mathrm{w}} \\
\left(\mathrm{mm} \mathrm{y}^{-1}\right)\end{array}$ & $\begin{array}{c}\mathrm{P}_{\mathrm{AH}}^{-1} \\
\left(\mathrm{~mm} \mathrm{y}^{-1}\right)\end{array}$ \\
\hline \multirow[t]{5}{*}{$\mathrm{HP} \mathrm{Mg}$} & 1 & 336 & 0.80 & 1.49 \\
\hline & 3 & 336 & 0.74 & 0.60 \\
\hline & 4 & 336 & 1.84 & 3.76 \\
\hline & 5 & 336 & 0.79 & 1.41 \\
\hline & 6 & 336 & 0.78 & 1.37 \\
\hline \multirow[t]{6}{*}{ PLLA-HP Mg } & 1 & 336 & 1.96 & 11.36 \\
\hline & 2 & 336 & 1.92 & 4.82 \\
\hline & 3 & 336 & 1.88 & 3.89 \\
\hline & 4 & 336 & 0.55 & 0.06 \\
\hline & 5 & 336 & 0.75 & 0.85 \\
\hline & 6 & 336 & 0.68 & 0.10 \\
\hline \multirow[t]{6}{*}{ AZ91 } & 1 & 336 & 1.95 & 10.14 \\
\hline & 2 & 336 & 1.93 & 6.2 \\
\hline & 3 & 336 & 2.03 & 15.36 \\
\hline & 4 & 336 & 1.93 & 6.94 \\
\hline & 5 & 336 & 1.07 & 1.60 \\
\hline & 6 & 336 & 1.03 & 1.57 \\
\hline \multirow[t]{5}{*}{ PLLA-AZ91 } & 2 & 336 & 0.74 & 0.6 \\
\hline & 3 & 336 & 1.89 & 4.43 \\
\hline & 4 & 336 & 1.18 & 2.82 \\
\hline & 5 & 336 & 0.62 & 0.10 \\
\hline & 6 & 336 & 0.68 & 0.12 \\
\hline
\end{tabular}

* The corrosion rate $P_{\mathrm{AH}}\left(\mathrm{mm} \mathrm{y}^{-1}\right)$ was evaluated using the volume of evolved hydrogen per unit area per day * The corrosion rate, $P_{\mathrm{W}}\left(\mathrm{mm} \mathrm{y}^{-1}\right)$ using the weight loss of sample

The average corrosion rates obtained from the hydrogen evolution volume were higher than the corrosion rates obtained from the weight loss for all samples. Table 2 indicates that overall corrosion rate of $\mathrm{Mg}$ samples with hole ranked as: HP Mg < PLLA-AZ91 < PLLA-HP Mg < AZ91. The corrosion rate of Mg samples without hole ranked as: PLLA-HP Mg < PLLA-AZ91 < HP Mg < AZ91. This may be attributed to the greater impact of PLLA coating layer that successfully protecting the surface (Zainal Abidin et al. 2011). Figure 9 (a) and 9 (b) showS the surface appearance of PLLA-HP Mg 5 and PLLA-AZ91 6 after immersion tests for 14 days and before corrosion product removal.

The PLLA layer was still attached to the samples surface with white corrosion products seen below the coating. It can clearly see that corrosion started at the edge of sample where delamination occurred and causing the breakdown of coated layer. Figure 10 shows the surface morphologies of uncoated HP Mg 3, AZ91 2, PLLA-HP Mg 2 and PLLA-AZ91 2 after immersion tests were done and before removal of corrosion product respectively. According to Figure 10, there were white corrosion products on the surface of each specimen. In the corrosion product, some cracks appear which is due to the shrinkage of the corrosion product during drying. For uncoated samples, the white corrosion product on the substrate surface is expect hydroxyapatite, heavily
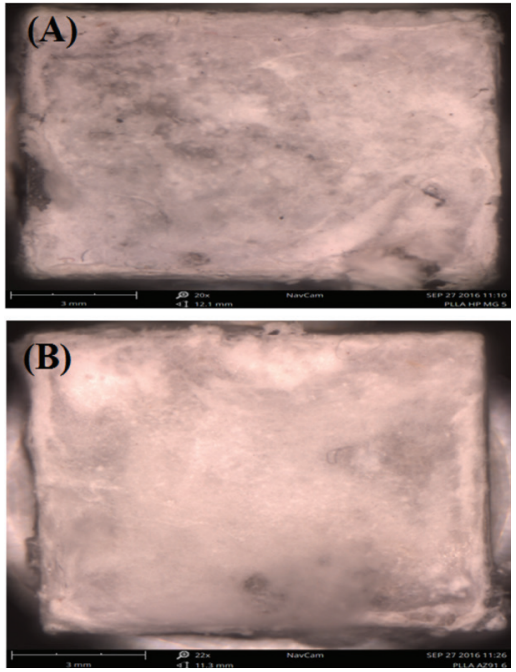

FIGURE 9. Surface appearance of samples PLLA-HP Mg 5 (A) and PLLA-AZ91 6 (B)

carbonated apatite and slightly carbonated apatite form and was confirmed through EDX done to the samples as shown in Figure 12 (Hiromoto 2015).

Figure 11 presents the surface appearance after corrosion product removal after 14 days of immersion in Hanks' solution. 

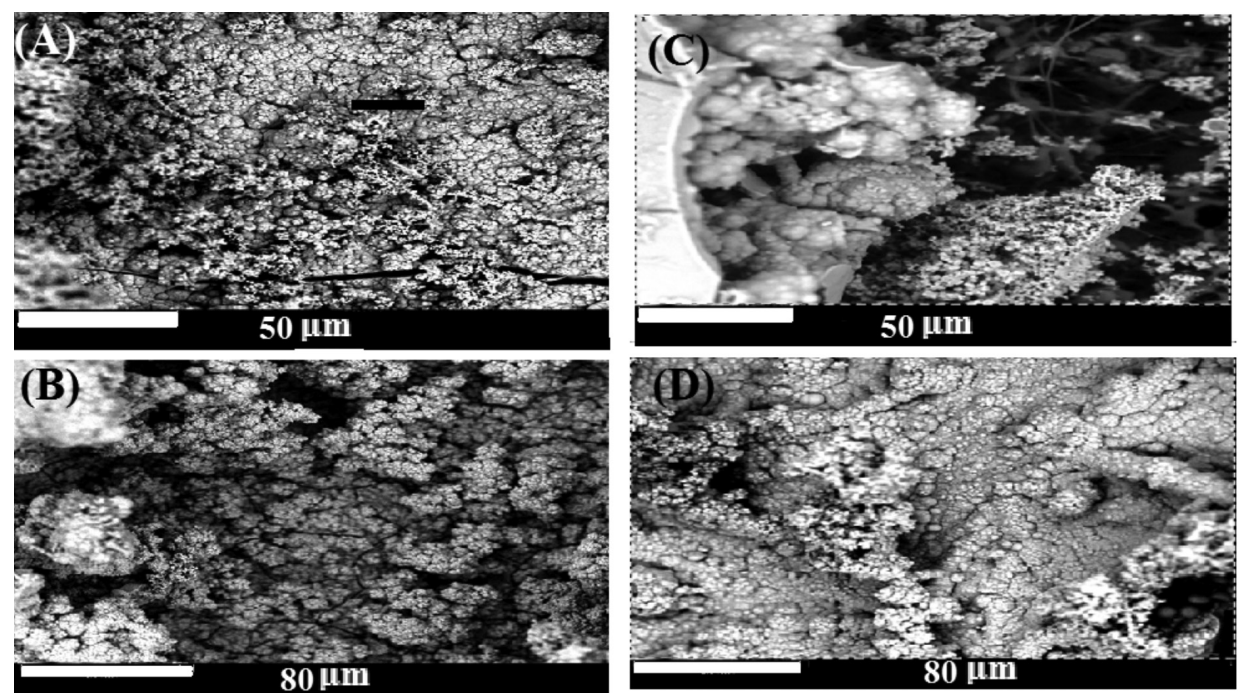

FIGURE 10. SEM surface morphologies of HP Mg (A), AZ91 (B), PLLA-HP Mg (C) and PLLA-AZ91 (D)
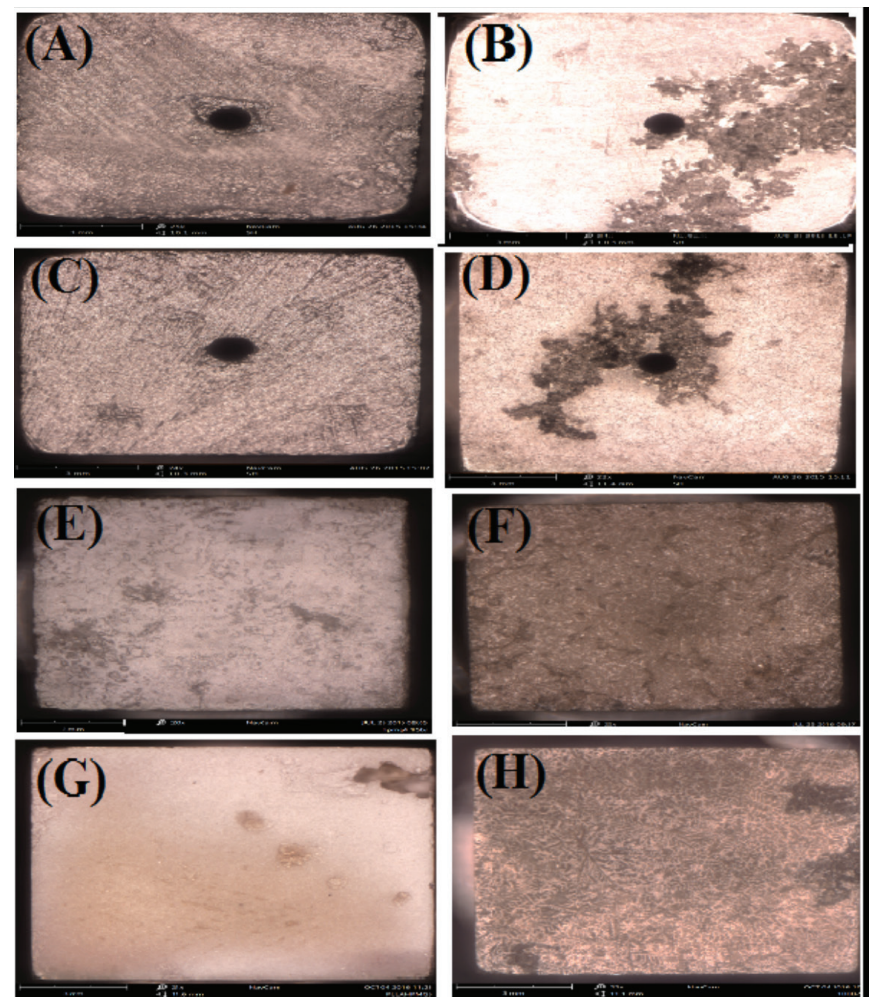

FIGURE 11. Surface appearance of corroded samples HP Mg 3 (A), AZ91 2 (B), PLLA-HP Mg 2 (C), PLLA-AZ91 2 (D), HP Mg 4 (E), AZ91 5 (F), PLLA-HP Mg 5 (G) and PLLA-AZ91 6 H)

From Figure 11(a), the surface of uncoated samples HP Mg 3 showed heterogeneous corrosion, severely corroded areas that were adjacent to the samples edge. This indicated that substrate suffered shallow localized corrosion while uncoated AZ91 2 from Figure 11(b) undergone similar amount of somewhat deeper localized corrosion known as pitting corrosion. The surface appearance of HP Mg 4 (Figure 11(e)) which had shown incubation period has superficial corrosion over the sample surface and deep heterogenous corrosion in a few places. The surface appearance of AZ91 5 (Figure 11(f)) was consistent with heterogenous corrosion having spread over sample surface. For coated samples with hole PLLAHP Mg 2 (Figure 11(c)), fewer flaws and tiny corrosion pits were observed on the cleaned surface as corrosion resistant coating should delay initiation of biodegradation. For sample PLLA-AZ91 2 (Figure 11(d)), there was pitting beneath the PLLA layer in which it started from hole. From the figures, it is obvious that the crevice corrosion started at hole and spread to the other area. Sample coated 

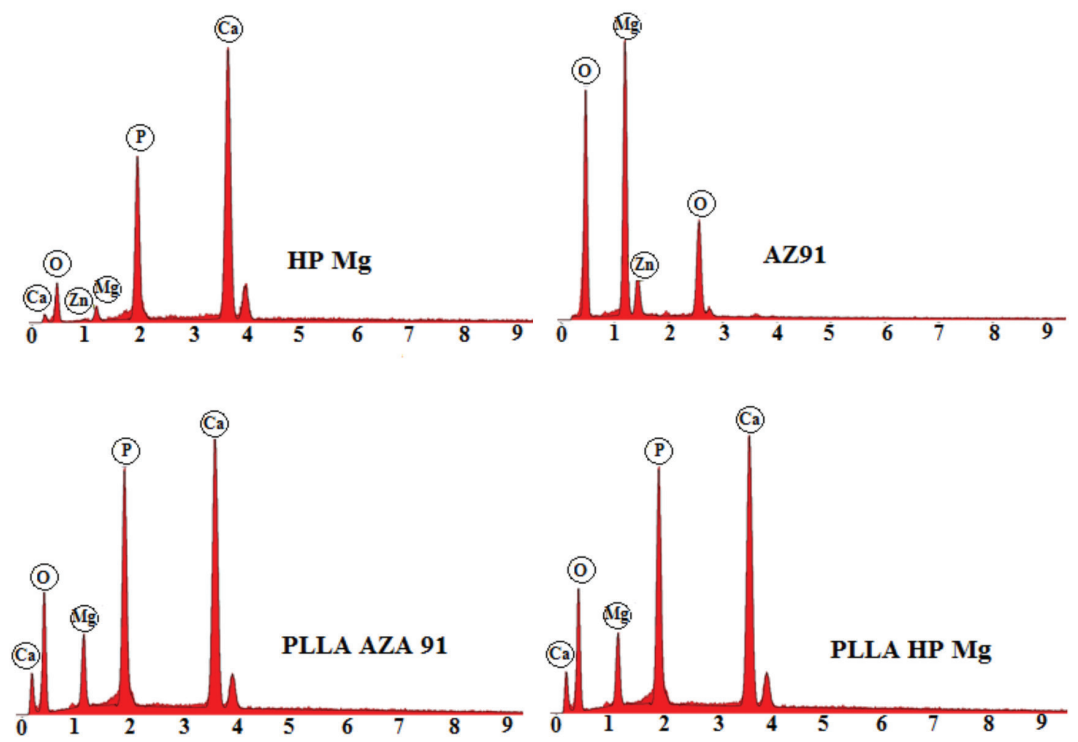

FIGURE 12. EDX analyses of corrosion products on the surface (HP Mg),

AZ91, PLLA-HP Mg 2 (C), PLLA-AZ91

without hole, PLLA-HP Mg 5 (Figure 11(g)) underwent heterogenous corrosion which deeper pit was seen on the edge of sample. Its enable coating to inhibit and or avoid localized corrosion while generating degradation on the surface of Mg. For PLLA-AZ91 6 (Figure 11(h)), sample underwent filiform corrosion. After removal of PLLA layer after 14 days immersion test, it can be seen that some flakes pattern formed on the sample's surface. The appearances of coated and uncoated HP Mg after corrosion product removal obtained from this research are similar with previous study (Rojaee et al. 2013; Zainal Abidin et al. 2015; Zhao et al. 2014). In Hank's solution, corrosion occurred due to oxide film breakdown and the attack onto the weak part of oxide film and reached the surface of $\mathrm{Mg}$.

Figure 12 shows overall EDX analyses of corrosion product on the surface after immersion test. The EDX results show that corrosion product of all samples after immersion test were mainly composed of $\mathrm{Ca}, \mathrm{P}, \mathrm{O}$ and $\mathrm{Mg}$ except sample of AZ91. There are additional compound found on corrosion product of AZ91 such as $\mathrm{C}, \mathrm{Zn}$ and $\mathrm{Cl}$. The EDX spectra proved that $\mathrm{Ca} / \mathrm{P}$ might cause formation of hydroxyapatite and it can be speculated that $\mathrm{Mg}$ hydroxide, amorphous $\mathrm{Ca} / \mathrm{P}$ and or $\mathrm{Mg}$ apatite amorphous compound deposited on surface where these compound comes from Hank's solution.

When polymer coated onto $\mathrm{Mg}$, it would be expected that, it provides longer incubation period during the initial stage of immersion (Yamamoto \& Hiromoto 2009). From Figure 11, it can be concluded that $\mathrm{Mg}$ samples degradation initiated at areas where the coating was damaged (Gu et al.2013). Some samples underwent filiform corrosion and leaved flakes pattern on the sample surface due to water slipped in between fibres of PLLA layer to reach into $\mathrm{Mg}$ surface.

\section{CONCLUSION}

The $\mathrm{CO}_{2}$ bubbled at partial pressure of 0.009 atm successfully maintained the solution $\mathrm{pH}$ throughout the experiment. Corrosion performance of $\mathrm{HP} \mathrm{Mg}$, AZ91, PLLAHP Mg and PLLA-AZ91 measured by means of hydrogen evaluation tests was in agreement with the morphologies observed at SEM.

\section{ACKNOWLEDGEMENTS}

This research was supported by the Institute of Research Management \& Monitoring University Malaya through Postgraduate Research Grant (PG 211-2014B) and Fundamental Research Grant Scheme (FP026-2014B).

\section{REFERENCES}

Abdalla, A.h., Barakat, N.A.M. \& Lim, J.K. 2013. Influence of electrospinning and dip-coating techniques on the degradation and cytocompatibility of Mg-based alloy. Colloids and Surfaces A: Physicochemical and Engineering Aspects 42: 32-45.

Abdalla, A.h., Dewidar, M., Lim, J.H. \& Lim, J.K. 2014. Enhanced biocorrosion resistance of surface modified magnesium alloys using inorganic/organic composite layer for biomedical application. Ceramics International 40(Issue 1, Part B): 2237-2247.

Abdalla, A.h., Dewidar, M. \& Lim, J.K. 2012. Biocorrosion behavior and cell viability of adhesive polymer coated magnesium based alloys for medical implants. Applied Surface Science 261: 536-546.

Abdalla,A.h.,Hwang, M.G. \& Lim, J.K. 2012. In vitro bioactivity of titanium implants coated with bicomponent hybrid biodegradable polymers. J. Sol-Gel Sci.Technol.64: 756-764.

Abidin, N.I.Z., Rolfe, B., Owen, H., Malisano, J., Martin, D., Hofstetter, J., Uggowitzer, P.J. \& Atrens, A. 2013. The in vivo and in vitro corrosion of high-purity magnesium and 
magnesium alloys WZ21 and AZ91. Corrosion Science 75: 354-366

Agrawal, C. \& Ray, R. 2001. Biodegrable polymeric scaffolds for musculoskeletal tissue engineering. J. Biomed. Mater. Res. 55: 141-150.

Amalina, M.A., Hajime, N., Hideki, Y., Yoshiharu, K. \& Shigeyuki, N. 2009. Fabrication of aligned Poly(L-lactide) fibers by electrospinning and drawing. Macromolecular Materials and Engineering 294: 658-665.

Atrens, A., Liu, M. \& Zainal Abidin, N.I. 2011. Corrosion mechanism applicable to biodegradable magnesium implants: A review. Materials Science and Engineering B 176: 16091636.

Azad, A.M., McKelvey, S.L. \& Al-Firdaus, Z. 2008. Fabrication of antimicrobial Titania nanofibers by electrospinning. The AMMTIAC Quarterly 3(3): 3-7. http://ammtiac.alionscience. com/quarterly.

Cao, F., Shi, Z., Song, G., Liu, M. \& Atrens, A. 2013. Corrosion behaviour in salt spray and in $3.5 \% \mathrm{NaCl}$ solution saturated with $\mathrm{Mg}(\mathrm{OH}) 2$ of as-cast and solution heat-treated binary Mg-X alloys: $\mathrm{X}=\mathrm{Mn}, \mathrm{Sn}, \mathrm{Ca}, \mathrm{Zn}, \mathrm{Al}, \mathrm{Zr}, \mathrm{Si}$, Sr. Corrosion Science 76: 60-92.

Chen, X.N., Gu, Y.X., Lee, J.H., Lee, W.Y. \& Wang, H.J. 2012. Multifunctional surfaces with biomimetic nanofibres and drug-eluting micro-patterns for infection control and bone tissue formation. European Cells and Materials 24: 237-248.

Chiu, K.Y., Wong, M.H., Cheng, F.T. \& Man, H.C. 2007. Characterization and corrosion studies of fluoride conversion coating on degradable Mg implants. Surface \& Coatings Technology 202: 590-598.

Chu, P.K., Chen, J.Y., Wang, L.P. \& Huang, N. 2002. Plasmasurface modification of biomaterials. Materials Science and Engineering: R: Reports 36(5-6): 143-206.

Deitzel, J., Kleinmeyer, J., Harris, D. \& Beck, T.N. 2001. The effect of processing variables on the morphology of electrospun nanofibers and textiles. Polymer 42: 261-272.

Doshi, J. \& Reneker, D.H. 1995. Electrospinning process and applications of electrospun fibers. Journal of Electrostatics 35(2-3): 151-160.

Duan, Y., Wang, Z., Yan, W., Wang, S., Zhang, S. \& Jia, J. 2007. Preparation of collagen-coated electrospun nanofibers by remote plasma treatment and their biological properties. $J$. Biomater. Sci. Polym. Ed. 18(9): 1153-1164.

Frenot, A. \& Chronakis, I.S. 2003. Polymer nanofibers assembled by electrospinning. Current Opinion in Colloid \& Interface Science 8(1): 64-75.

Gu, Y., Bandopadhyay, S., Chen C.-f., Ning, C. \& Guo, Y. 2013. Long-term corrosion inhibition mechanism of microarc coated AZ31 Mg alloys for biomedical applications. Materials and Design 46: 66-75.

Hiromoto, S. 2015. Self-healing property of hydroxyapatite and octacalcium phosphate coaatings on pure magnesium and magnesium alloy. Corrosion Science 100: 284-294.

Iafisco, M., Foltran, I., Sabbatini, S., Tosi, G. \& Roveri, N. 2011. Electrospun nanostructured fibers of collagen-biomimetic apatite on titanium alloy. Hindawi Publishing Corporation.

Krikorian, V.\& Pochan, D.J. 2003. Poly (L-lactic)/layered silicate nanocomposite: Fabrication, characterization, and properties. Chem. Mater. 15: 4317-4324.

Shenoy, S.L., Bates, W.D., Frisch, H.L. \& Wnek, G.E. 2005. Role of chain entanglements on fiber formation during electrospinning of polymer solutions: Good solvent, nonspecific polymer-polymer interaction limit. Polymer 46(10): 3372-3384.
Liang, D., Hsiao, B.S. \& Chu, B. 2007. Functional electrospun nanofibrous scaffolds for biomedical applications. Advanced Drug Delivery Reviews 59: 1392-1412.

Niu, J., Yuan, G., Liao, Y., Mao, L., Zhang, J., Wang, Y., Huang, F., Jiang, Y., He, Y. \& Ding, W. 2013. Enhanced biocorrosion resistance and biocompatibility of degradable $\mathrm{Mg}-\mathrm{Nd}-\mathrm{Zn}-\mathrm{Zr}$ alloy by brushite coating. Materials Science and Engineering C 33: 4833-4841.

Pandey, A., Pandey, G.C. \& Aswath, P.B. 2008. Synthesis of polylactic acid-polyglycolic acid blends using microwave radiation. Journal of the Mechanical Behavior of Biomedical Materials 1(3): 227-233.

Qiao, Z., Shi, Z., Hort, N., Abidin, N.I.Z. \& Atrens, A. 2012. Corrosion behaviour of a nominally high purity $\mathrm{Mg}$ ingot produced by permanent mould direct chill casting. Corrosion Science 61: 185-207.

Ravichandran, R. 2009. Biomimetic surface modification of dental implant for enhanced osseointegration. Tesis Master of Engineering, National University of Singapore, Singapore (Unpublished).

Razavi, M., Fathi, M., Savabi, O., Razavi, S.M., Beni, B.H., Vashaee, D. \& Tayebi, L. 2014. Controlling the degradation rate of bioactive magnesium implants by electrophoretic deposition of akermanite coating. Ceramics International 40: 3865-3872

Rojaee, R., Fathi, M. \& Raeissi, K. 2013. Controlling the degradation rate of AZ91 magnesium alloy via sol-gel derived nanostructured hydroxyapatite coating. Materials Science and Engineering $C$ 33: 3817-3825.

Rojaee, R., Fathi, M. \& Raeissi, K. 2013. Electrophoretic deposition of nanostructured ydroxyapatite coating on AZ91 magnesium alloy implants with different surface treatments. Applied Surface Science 285P: 664-673.

Shah, P.N., Manthe, R.I., Lopina, S.T. \& Yun, Y.H. 2009. Electrospinning of L-tyrosine polyurethanes for biomedical applications. Polymer 50(10): 2281-2289.

Shi, Z. \& Atrens, A. 2011. An innovative specimen configuration for the study of Mg corrosion. Corrosion Science 53: 226-246.

Song, G. 2007. Control of biodegradation of biocompatable magnesium alloys. Corrosion Science 49(4): 1696-1701.

Staiger, M.P., Pietak, A.M., Huadmai, J. \& Dias, G. 2006. Magnesium and its alloys as orthopedic biomaterials: A review. Biomaterials 27(9): 1728-1734.

Virtanen, S. 2011. Biodegradable $\mathrm{Mg}$ and Mg alloys: corrosion and biocompatibility: A review. Materials science and Engineering B 176: 1600-1608.

Wen, C., Guan, S., Peng, L., Ren, C., Wang, X. \& Hu, Z. 2009. Characterizatian and degradation behavior of AZ31 alloy surface modified by bone-like hydroxypatite for implant application. Applied Surface Science 255(13-14): 6433-6438.

Wong, H.M., Yeung, K.W.K.Lam, K.O., Tam, V., Chu, P.K., Luk, K.D.K. \& Cheung, K.M.C. 2010. A biodegradable polymerbased coating to control the performance of magnesium alloy orthopaedic implants. Biomaterials 31(8): 2084-2096.

Yamamoto, A. \& Hiromoto, S. 2009. Effect of inorganic salts, amino acids and proteins on the degradation of pure magnesium in vitro. Materials Science and Engineering $C$ 29: $1559-1568$

Zainal Abidin, N.I., Forno, A.D., Bestetti, M., Martin, D., Beer, A. \& Atrens, A. 2015. Evaluation of coating for Mg Alloys for biomedical applications. Advanced Engineering Materials 17: 58-67. 
Zainal Abidin, N.I., Atrens, A.D., Martin, D. \& Atrens, A. 2011. Corrosion of high purity $\mathrm{Mg}, \mathrm{Mg} 2 \mathrm{Zn} 0.2 \mathrm{Mn}, \mathrm{ZE} 41$ and AZ91 in Hank's solution at 37'C. Corrosion Science 53: 3542-3556.

Zainal Abidin, N.I., Martin, D. \& Atrens, A. 2011. Corrosion of high purity Mg, AZ91, ZE41 and Mg2Zn0.2Mn in Hank's solution at room temperature. Corrosion Science 53: 862-872.

Zhang, R. \& Ma, P.X. 1998. Porous poly(L-lactic acid)/apatite composites created by biomimetic process. J. Biomed. Mater. Res. 45(4): 285-293.

Zhao, L., Liu, Q., Wang, J., Yang, W. \& Liu, L. 2014. One-step method for the fabrication of superhydrophobic surface on magnesium alloy and its corrosion protection, antifouling performance. Corrosion Science 80: 177-183.

Zhao, M.C., Liu, M., Song, G. \& Atrens, A. 2008. Influence of the B-phase morphology on the corrosion of the mg alloy AZ91. Corrosion Science 50: 1939-1953.

Zhao, M.C., Schmutz, P., Brunner, S., Liu, M., Song, G. \& Atrens, A. 2009. An exploratory study of the corrosion of mg alloys during interrupted salt spray testing. Corrosion Science 51: 1277-1292.
Department of Mechanical Engineering

Faculty of Engineering

University of Malaya

50603 Kuala Lumpur

Malaysia

*Corresponding author; email: Atikah_nafi@yahoo.com

Received: 21 March 2017

Accepted: 9 June 2017 